\title{
A COMPLEX INFLUENCE OF CHROMIUM AND ZINC CITRATES ON ANTIOXIDANT DEFENSE SYSTEM IN RATS' ORGANISM WITH AN EXPERIMENTALLY INDUCED DIABETES MELLITUS
}

Introduction. Since the diabetes mellitus is a genetically predetermined disease, preventive measures to postpone the onset of the disease or to avert its appearance are especially important for people from risk group. That is why it is so important to evaluate the role of some microelements in diabetes prevention. In particular, it is known that zinc plays an important role in insulin synthesis, accumulation and release by $\beta$-cells in pancreas, while its synergist chromium activates insulin receptors on cell membranes.

The aim of the study - to establish the effect of chromium and zinc citrates on the functioning of antioxidant system and on the content of lipid peroxidation products in rats'blood and tissues under the condition of experimental streptozotocin-induced diabetes mellitus.

Methods of the research. Experiments were conducted on white laboratory rats which were divided into three groups: 1 - the control group, 2, 3-research groups. Rats from the 1 and 2 groups received only basic ration, while chromium and zinc citrates solutions were added to the water of animals from the group 3 in $25 \mathrm{mcg} \mathrm{Cr} / \mathrm{kg}$ and 50 $\mathrm{mg} \mathrm{Zn/kg} \mathrm{of} \mathrm{body} \mathrm{weight} \mathrm{dosage.} \mathrm{An} \mathrm{experimental} \mathrm{diabetes} \mathrm{mellitus} \mathrm{(EDM)} \mathrm{was} \mathrm{induced} \mathrm{in} \mathrm{animals} \mathrm{from} 2$ and 3 research groups on the $25^{\text {th }}$ day of the experiment, after 24-hour fasting, by intraperitoneal injection of Streptozotocin in $45 \mathrm{mg} / \mathrm{kg}$ bodyweight dosage. Materials for the research were rats' blood and tissues that were received after decapitation. The content of lipid hydroperoxides in blood and tissues was determined by a method that requires protein sedimentation by a trichloroacetic acid (TCA) and further addition of ammonium thiocyanate to the solution. The MDA content was measured by means of a colored reaction of malondialdehyde with the thiobarbituric acid. The activity of superoxide dismutase (SOD, EC 1.1.15.1.) was determined by a method where nitrotetrazolium is reduced by superoxide radicals. Glutathione peroxidase activity (GP, EC 1.11.1.9.) was measured by the speed of reduced glutathione oxidation. The activity of catalase (EC 1.11.1.6.) was measured by hydrogen peroxide ability to form a stable colored complex with molybdenum salts. The activity of glutathione reductase (GR, EC 1.6.4.2) was measured by a speed of glutathione reduction in the presence of NADPH. The content of reduced glutathione was gauged by the level of thionitrophenol anion formation as a result of SH-groups of glutathione and 5.5-dithiobis-(2nitrobenzoic acid) reaction.

Results and Discussion. It was determined during the research that lipid hydroperoxides (LHP) and MDA contents in rats' blood, skeletal muscles and pancreas were increased, while the activity of antioxidant defense system enzymes and reduced glutathione content were decreased under the condition of streptozotocin-induced DM. Under the condition of combined chromium and zinc citrates addition to the diet of rats from group 3 we observed the credible decrease of lipid hydroperoxides content, while the increased activity of antioxidant enzymes compared to those indexes from group 2.

Conclusions. The received results indicate the normalization of lipids peroxidation processes and antioxidant defense under the influence of chromium and zinc citrates in animals with hyperglycemia. The further research of antioxidant properties of organic compounds of these microelements will let to develop medical remedies for diabetes prevention and treatment.

KEY WORDS: rats; antioxidant system; zinc citrate; chromium citrate; experimentally induced diabetes.

Diabetes mellitus is an endocrine disease that occurs as a result of an absolute or relative insulin deficiency, which leads to the defection of all types of metabolism. The appearance of this disease is predetermined by the influence of various exogenous, immune, endocrine and genetic factors or by their combination [1]. Regardless of its mechanism, the insulin deficiency leads to carbohydrates me(c) L. S. Logoyda, 2017. tabolism disorders at the first place, which leads to hyperglycemia. Glucose accumulation in blood leads to glycolysis and TCA intensification that results in an intensified work of electron transport chain in mitochondria. A membrane potential rises to a critical point that causes a block of a III mitochondrial complex, an electron from coenzyme-Q10 passes on to an oxygen molecule and a superoxide anion $\left(\cdot \mathrm{O}^{2}\right)$ is being formed [2]. In a state of hyper- 
glycemia a mitochondrial superoxide dismutase (Mn-SOD) cannot cope with the excess of the superoxide anions and the oxidative stress begins. Superoxide anion converts to the hydroxyl-radical, hydrogen peroxide and peroxynitrite after interaction with other compounds $[3,4]$. The oxidative stress goes along with proteins nitrification, lipids peroxidation, DNA fragmentation, changes of cell signaling, activation of PARP-1, which results in metabolism and mechanisms of cell signaling disorders that are typical for diabetes complications [3]. As a result of pathological changes that occur under the condition of diabetes a lower glucose intake from blood, a local decrease of intracellular glucose reserve in a form of glycogen and triacylglycerides, an energetic depletion of the organism are seen. Altogether it leads to energy substrates deficiency that directly correlates with defense systems efficiency, in particular of the antioxidant one [5]. The antioxidant defense system controls and restrains all stages of free radical reactions starting with their initiation and up to the hydroperoxides and malondialdehyde formation [6-8].

Since the diabetes mellitus is a genetically predetermined disease, preventive measures to postpone the onset of the disease or to avert its appearance are especially important for people from risk group. That is why it is so important to evaluate role of some microelements in diabetes prevention. In particular, it is known that zinc plays an important role in insulin synthesis, accumulation and release by $\beta$-cells in pancreas, while its synergist chromium activates insulin receptors on cell membranes.

Therefore, the aim of our research was to establish the effect of chromium and zinc citrates on the functioning of antioxidant system and on the content of lipid peroxidation products in rats' blood and tissues under the condition of experimental streptozotocin-induced diabetes mellitus.

MATERIALS AND METHODS. The research was implemented on white laboratory rats, which were held in the Institute of Animal Biology of NAAS vivarium. It was completed in accordance to recommendations, approved by European Convention on vertebrate protection, used for experimental and scientific purposes (Strasburg 1986), and to "Bioethical expertise of preclinical and other scientific researches, implemented on animals (Kyiv, 2006). Animals with body weight from 150 to $170 \mathrm{~g}$ were divided into three groups, each consisted of 7 animals: 1 - the control group, 2, 3-research groups. For 30 days of the research rats from the 1 and 2 groups received only basic ration, while chromium and zinc citrates solutions were added to the water of animals from group 3 in $25 \mathrm{mcg} \mathrm{Cr} / \mathrm{kg}$ and $50 \mathrm{mg}$ $\mathrm{Zn} / \mathrm{kg}$ body weight dosage. An experimental diabe- tes mellitus (EDM) was induced in animals from 2 and 3 research groups on the $25^{\text {th }}$ day of the experiment, after 24-hour fasting, by intraperitoneal injection of Streptozotocin ("Sigma", USA) in $45 \mathrm{mg} / \mathrm{kg}$ bodyweight dosage. Hyperglycemia was detected using portable glucose meter ("Gamma-M"), by measuring sugar level in blood taken from the tail vein. The animals were withdrawn from the experiment by means of decapitation under light ether anesthesia. Materials for the research were rats' blood and homogenates of liver, skeletal muscles and pancreas, in which the content of lipid peroxidation products and the activity of antioxidant defense enzymes were measured.

The content of lipid hydroperoxides in blood and tissues was determined by a method that requires protein sedimentation by a trichloroacetic acid (TCA) and further addition of ammonium thiocyanate to the solution [9]. The MDA content was measured by means of a colored reaction of malondialdehyde with the thiobarbituric acid [10]. The activity of superoxide dismutase (SOD, EC 1.1.15.1.) was determined by a method where nitrotetrazolium is reduced by superoxide radicals [11]. Glutathione peroxidase‘s activity (GP, EC 1.11.1.9.) was measured by the speed of reduced glutathione oxidation [12]. The activity of catalase (EC 1.11.1.6.) was measured by hydrogen peroxide's ability to form a stable colored complex with molybdenum salts [13]. The activity of glutathione reductase (GR, EC 1.6.4.2) was measured by a speed of glutathione reduction in the presence of NADPH [14]. The content of reduced glutathione was gauged by the level of thionitrophenol anion formation as a result of SHgroups of glutathione and 5.5'-dithiobis-(2-nitrobenzoic acid) reaction [15].

The received digital data was statistically processed using a computer program "Statistika". Student's test was used to determine significant difference between averages.

RESULTS AND DISCUSSION. In the process of the research it was established that under the condition of streptozotocin-induced diabetes the content of lipid hydroperoxides was increased in 1.9 times in blood of rats from group 2 (tab. 1), while the content of MDA didn't change credibly, but the activity of SOD was decreased in 1.2 times and of glutathione peroxidase in 1.4 times. Also, the tendency to decreased level of reduced glutathione and glutathione reductase was observed in these animals compared to the control group (tab. 1). This indicates lipid peroxidation induction and the decreased activity of antioxidant system enzymes in a state of diabetes.

The credible decrease of hydroperoxides content in blood in 1.8 times was established under 
Table 1 - The content of lipid peroxidation products and the activity of antioxidant system enzymes in rats' blood in a state of experimental diabetes and under the complex effect of zinc and chromium citrates $(M \pm m, n=7)$

\begin{tabular}{|c|c|c|c|}
\hline \multirow{3}{*}{ Indexes } & \multicolumn{3}{|c|}{ Animal groups } \\
\hline & Control & & esearch \\
\hline & 1 & 2 (with diabetes) & 3 (with diabetes+Cr+Zn) \\
\hline $\begin{array}{l}\text { Lipid hydroperoxides, standard units/g } \\
\text { of protein }\end{array}$ & $0.5225 \pm 0.0168$ & $0.996 \pm 0.134^{* *}$ & $0.545 \pm 0.0276^{\#}$ \\
\hline MDA, nmoles/g of protein & $3.84 \pm 0.106$ & $3.94 \pm 0.136$ & $3.655 \pm 0.066$ \\
\hline SOD, standard units/g of protein & $26.53 \pm 0.509$ & $22.74 \pm 0.715^{\star * \star}$ & $27.15 \pm 0.866^{\#}$ \\
\hline Catalase, $\mathrm{mcmoles} / \mathrm{min}$ for $1 \mathrm{mg}$ of protein & $18.38 \pm 0.373$ & $18.945 \pm 1.4$ & $20.362 \pm 1.011$ \\
\hline Reduced glutathione, mcmoles/l & $0.73 \pm 0.027$ & $0.62 \pm 0.066$ & $0.87 \pm 0.042^{* * * \#}$ \\
\hline $\begin{array}{l}\text { Glutathione peroxidase, nmoles/min } \\
\text { for } 1 \mathrm{mg} \text { of protein }\end{array}$ & $23.05 \pm 0.696$ & $16.56 \pm 0.366^{* \star \star}$ & $27.93 \pm 0.489^{* \star \star \# \# \#}$ \\
\hline $\begin{array}{l}\text { Glutathione reductase, } \mathrm{mcmoles} / \mathrm{min} \\
\text { or } 1 \mathrm{mg} \text { of protein }\end{array}$ & $1.36 \pm 0.132$ & $1.25 \pm 0.131$ & $1.405 \pm 0.055$ \\
\hline
\end{tabular}

Note. Here and in the Table 2-4: * statistically creadible differences between animals from 2 and 3 groups and animals from group 1 (control): * $-p<0.05 ;{ }^{* \star}-p<0.01 ;{ }^{* \star \star}-p<0.001$; \# statistically creadible differences between animals from group 3 and group 2: $\#-p<0.05 ; \#-p<0.01 ; \# \#-p<0.001$.

the condition of complex addition of chromium and zinc citrates to the ration of rats from group 3 , but the SOD's activity was increased in 1.2 times, glutathione peroxidase's activity - in 1.7 times and the content of reduced glutathione - in 1.4 times compared to those indexes in group 2. At the same time the activity of glutathione peroxidase and the content of reduced glutathione were increased in 1.2 times compared to the control group (tab. 1).

The received results confirm the normalization of lipid peroxidation processes in blood and the increase of antioxidant defense system enzymes under the influence of chromium and zinc citrates.

The liver maintains the constant glucose blood level. It was established that the content of MDA in rats' liver from group 2 (tab. 2) was increased in 1.4 times, but the content of reduced glutathione was decreased in 2.7 times, also activities of glutathione peroxidase and glutathione reductase were decreased in 1.4 and 1.9 times respectively. Also the tendency to increased level of lipid hydroperoxides and catalase's activity, while the tendency to decreased level of SOD activity were observed in a researched tissue, compared to animals from the control group, although these changes were not credible. But it was established that the content of MDA in rats' liver from group 3 was decreased in 1.7 times, but the content of reduced glutathione was increased in 2.3 times, also activities of SOD, glutathione peroxidase and glutathione reductase were increased in 1.4 and 1.6 times respectively, compared with animals from group 2. Besides that a credible decrease of MDA content and increase of SOD's, catalase's and glutathione peroxidase's activities were observed, compared to animals from the control group.

It is established that in a physiological state under the clear insulin regulation muscle tissue is one of the main glucose consumers. We detected a credible increase of lipid hydroperoxides content in 3.1 times, MDA content in 1.4 times, but the decrease of SOD's, catalase's, glutathione peroxidase's and glutathione reductase's activities in 1.2, 1.6, 2.0 and 2.3 times respectively in the muscle tissue of rats from group 2 compared to those indexes in animals from the 1 (control) group (tab. 3).

Since the muscle tissue is an insulin sensitive tissue, in a state of diabetes the speed of glucose

Table 2 - The content of lipid peroxidation products and the activity of antioxidant system enzymes in rats' liver in a state of experimental diabetes and under the complex effect of chromium and zinc citrates $(M \pm m, n=7)$

\begin{tabular}{|c|c|c|c|}
\hline \multirow{3}{*}{ Indexes } & \multicolumn{3}{|c|}{ Animal groups } \\
\hline & Control & & search \\
\hline & 1 & 2 (with diabetes) & 3 (with diabetes+Cr+Zn) \\
\hline $\begin{array}{l}\text { Lipid hydroperoxides, standard units/g } \\
\text { of protein }\end{array}$ & $0.163 \pm 0.0098$ & $0.241 \pm 0.061$ & $0.144 \pm 0.007$ \\
\hline MDA, nmoles/g of protein & $3.569 \pm 0.154$ & $4.887 \pm 0.309^{* *}$ & $2.919 \pm 0.09^{* * \# \#}$ \\
\hline SOD, standard units/mg of protein & $41.882 \pm 1.249$ & $39.375 \pm 1.107$ & $54.22 \pm 1.066^{* \star \star \# \# \#}$ \\
\hline Catalase, $\mathrm{mcmoles} / \mathrm{min}$ for $1 \mathrm{mg}$ of protein & $7.57 \pm 0.366$ & $8.77 \pm 0.479$ & $8.817 \pm 0.174^{\star *}$ \\
\hline Reduced glutathione, mcmoles/l & $4.6 \pm 0.326$ & $1.73 \pm 0.0625^{\star * *}$ & $4.07 \pm 0.166^{\# \# \#}$ \\
\hline $\begin{array}{l}\text { Glutathione peroxidase, nmoles/min } \\
\text { for } 1 \mathrm{mg} \text { of protein }\end{array}$ & $9.02 \pm 0.345$ & $6.37 \pm 0.208^{* *}$ & $10.37 \pm 0.29^{* * \# \#}$ \\
\hline $\begin{array}{l}\text { Glutathione reductase, } \mathrm{mcmoles} / \mathrm{min} \\
\text { for } 1 \mathrm{mg} \text { of protein }\end{array}$ & $1.53 \pm 0.12$ & $0.818 \pm 0.13^{\star \star \star}$ & $1.31 \pm 0.107^{\# \#}$ \\
\hline
\end{tabular}


Table 3 - The content of lipid peroxidation products and the activity of antioxidant system enzymes in rats' muscles in a state of experimental diabetes and under the complex effect of zinc and chromium citrates $(M \pm m, n=7)$

\begin{tabular}{|l|c|c|c|}
\hline \multirow{2}{*}{\multicolumn{1}{|c|}{ Indexes }} & \multicolumn{2}{c|}{ Animal groups } \\
\cline { 2 - 4 } & Control & \multicolumn{2}{c|}{ Research } \\
\cline { 2 - 4 } & 1 & 2 (with diabetes) & 3 (with diabetes+Cr+Zn) \\
\hline $\begin{array}{l}\text { Lipid hydroperoxides, standard units/g } \\
\text { of protein }\end{array}$ & $0.15 \pm 0.0052$ & $0.47 \pm 0.0475^{* * *}$ & $0.23 \pm 0.0538^{\# \#}$ \\
\hline MDA, nmoles/g of protein & $1.49 \pm 0.08$ & $2.098 \pm 0.138^{* *}$ & $1.67 \pm 0.129^{\#}$ \\
\hline SOD, standard units/mg of protein & $63.43 \pm 1.05$ & $51.67 \pm 0.853^{* * *}$ & $67.88 \pm 1.81^{* \# \#}$ \\
\hline Catalase, mcmoles/min for 1 mg of protein & $18.78 \pm 0.972$ & $11.35 \pm 0.319^{* * *}$ & $15.11 \pm 1.078^{* \# \#}$ \\
\hline Reduced glutathione, mcmoles/l & $0.33 \pm 0.015$ & $0.257 \pm 0.031$ & $0.305 \pm 0.0192$ \\
\hline $\begin{array}{l}\text { Glutathione peroxidase, nmoles/min } \\
\text { for 1 mg of protein }\end{array}$ & $37.3 \pm 2.6$ & $18.68 \pm 0.989^{* * *}$ & $34.11 \pm 0.809^{\# \# \#}$ \\
\hline $\begin{array}{l}\text { Glutathione reductase, mcmoles/min } \\
\text { for 1 mg of protein }\end{array}$ & $0.47 \pm 0.045$ & $0.207 \pm 0.008^{* * *}$ & $0.60 \pm 0.061^{\# \# \#}$ \\
\hline \hline
\end{tabular}

phosphorylation to the glucose 6-phosphate is decreased, as a result the intensity of lipolysis rises as well as the content of free unsaturated fatty acids that can be oxidated in a process of lipid peroxidation. The increase of lipid peroxidation products in a state of diabetes is also related to the modification of antioxidant enzymes by the active oxygen and glucose.

With the addition of $\mathrm{Cr}$ and Zn citrates to rats' ration from group III a decrease of lipid hydroperoxides content in 2 times and MDA content in 1.2 times was observed, but the activities of SOD, glutathione peroxidase, glutathione reductase were increased in 1.3, 1.8 and 2.9 times respectively, compared to those indexes in animals from group 2. Besides that a credible decrease of catalase's activity in 1.2 times was established in group 3 compared to the group 1 (control).

Pancreas is a complex alveolar gland with both exocrine (excretory) and endocrine (incretory) functions [1]. Regardless of the extent of compensation of the diabetes there is a direct correlation between the intensity of free radical oxidation, dyslipidemia and triglyceridemia that impact negatively on the functional activity of $\beta$-cells [16-18]. Active forms of oxygen oxidate phospholipids of mitochondrial membranes in $\beta$-cells in pancreas, which leads to the outflow of protons from the electron transport chain and the decreased ATP production that is a critical factor in the process of insulin synthesis [19]. The oxidative modification of proteins and lipid peroxidation are closely connected and form the pathological circle which leads to the oxidative stress progression in pancreatic cells.

It was established in the research that in rats' pancreas from group 2 contents of hydroperoxides and MDA were increased in 2 and 1.9 times respectively compared to the control group (tab. 4). At the same time with the complex addition of chromium and zinc citrates their content in rats' pancreas from group 3 was decreased in 1.6 and 1.8 times respectively, compared to animals from group 2.

The decrease of SOD activity in 2.4 times, the content of reduced glutathione in 2.0 times, glutathione peroxidase and glutathione reductase activities in 1.3 and 1.4 times respectively were observed in rats' pancreas from group 2, although the activity of catalase was increased in 1.3 times compared to those indexes in animals from the control group.

Superoxide dismutase is a key enzyme of the antioxidant defense system, it dissactivates one of active oxygen forms - superoxide radical $\left(\mathrm{O}_{2}-\right)$ with the formation of hydrogen peroxide $[6,7]$. The de-

Table 4 - The content of lipid peroxidation products and the activity of antioxidant system enzymes in rats' pancreas in a state of the experimental diabetes and under the complex effect of zinc and chromium citrates $(M \pm m, n=7)$

\begin{tabular}{|l|c|c|c|}
\hline \multirow{2}{*}{ Indexes } & \multicolumn{3}{c|}{ Animal groups } \\
\cline { 2 - 4 } & Control & \multicolumn{2}{c|}{ Research } \\
\cline { 2 - 4 } & 1 & 2 (with diabetes) & 3 (with diabetes+Cr+Zn) \\
\hline $\begin{array}{l}\text { Lipid hydroperoxides, standard units/g } \\
\text { of protein }\end{array}$ & $0.36 \pm 0.029$ & $0.71 \pm 0.04^{* * *}$ & $0.45 \pm 0.0186^{* * \# \#}$ \\
\hline MDA, nmoles/g of protein & & & $1.60 \pm 0.123^{\# \# \#}$ \\
\hline SOD, standard units/mg of protein & $38.12 \pm 2.252$ & $15.84 \pm 0.65^{* * *}$ & $40.19 \pm 0.607^{\# \#}$ \\
\hline Catalase, mcmoles/min for 1 mg of protein & $4.07 \pm 0.24$ & $5.29 \pm 0.432^{* * *}$ & $4.16 \pm 0.145^{\#}$ \\
\hline Reduced glutathione, mcmoles/l & $1.19 \pm 0.067$ & $0.59 \pm 0.025^{* * *}$ & $1.06 \pm 0.0494^{\# \#}$ \\
\hline $\begin{array}{l}\text { Glutathione peroxidase, nmoles/min } \\
\text { for 1 mg of protein }\end{array}$ & $31.31 \pm 1.502$ & $24.5 \pm 1.21^{* *}$ & $31.14 \pm 2.251^{\# \#}$ \\
\hline $\begin{array}{l}\text { Glutathione reductase, mcmoles/min } \\
\text { for 1 mg of protein }\end{array}$ & $0.86 \pm 0.0373$ & $0.61 \pm 0.0159^{* * *}$ & $0.78 \pm 0.0366^{\# \# \#}$ \\
\hline
\end{tabular}


creased SOD activity in a state of experimental diabetes mellitus can occur due to the hydrogen peroxide accumulation which is SOD's inhibitor and catalase's substrate, activity of which increases.

The increase of SOD activity in 2.5 times, of the content of reduced glutathione in 1.8 times, glutathione peroxidase and glutathione reductase activities in 1.3 times were observed in rats' pancreas from group 3 , although the activity of catalase was decreased in 1.3 times compared to those indexes in animals from group 2.

Overall, the decreased activity of antioxidant defense system enzymes in blood, as well as in researched tissues, in animals from group 2 under the condition of experimental diabetes is conditioned by depletion of their reserves that are consumed for the neutralization of free radicals. The decreased concentration of GSH is related not only with its intensified consumption and insufficient reduction (namely with the change of glutathione peroxidase and glutathione reductase activities) but also with the defection of glutathione synthesis and interchange.

The decrease of lipid hydroperoxides and MDA content in rats blood and tissues from group 3 under the influence of zinc and chromium citrates indicate the inhibitory effect of researched elements (with the increment usage) on lipid peroxidation processes in blood, liver, muscles and pancreas - organs, that are characterized by a high metabolic activity. The explanation of mechanisms of chromium and zinc inhibitory effect on peroxidation processes in rats' blood and tissues should be sought in the activation of glutathione-dependent antioxidant enzyme system, which neutralizes lipid peroxides and maintains the reduced condition of $\mathrm{SH}$-groups of proteins and therefore assures their functional activity [20].

Antioxidant effect of $\mathrm{Cr}$ (3) may be conditioned by its ability to regulate expression of antioxidant enzymes' genes [21]. The activation of redoxsensitive genes of antioxidant enzymes that are necessary for the cell defense from toxic effect of oxidative stress occurs with the aid of active oxygen forms. Main regulatory system in the cell that controls genes expression with the aid of active oxygen forms is presented by MAP (Mitogen-Activated Protein)-kinases. Active oxygen forms stimulate a cascade of MAP-kinases and regulate the activity of transcription factors NF-kB, AP-1 i ATF-2 [22]. After conducted analysis of literature data and the results of our research we have a basis to affirm that chromium affects the synthesis of antioxidant enzymes by the means of MAP-kinases' activity regulation. Besides that, the activity of antioxidant system enzymes may change because of Chromium effect on cofactors content and physiological accessibility.

One of important Zinc functions is its participation in antioxidant defense system [23, 24]. Zinc can activate synthesis of $\mathrm{Cu} / \mathrm{Zn}$-dependent SOD in liver [25]. Zinc can compete with Iron and Copper, as its antagonists, for connections with cell membranes and reduce free radicals formation, hence implement a direct antioxidant effect [26]. Also, Zinc can protect $\mathrm{SH}$-groups of proteins by means of direct connection with them or by dimensional hindering for binding with any other protein sites that are in a close proximity to SH-groups. Zinc has the ability to lessen the damage of cells that already have elements of site-specific oxidative damage.

Despite that proves of antioxidant properties of $\mathrm{Zn}$ and $\mathrm{Cr}$ are persuasive, the exact mechanisms are still recondite. Further researches will allow revealing mechanisms of antioxidant properties of $\mathrm{Cr}$ and $\mathrm{Zn}$ better and this will provide an opportunity to ascertain new properties of organic compounds of these microelements and to elaborate new medication for the prevention and treatment of diabetes mellitus.

\section{LIST OF LITERATURE}

1. Кузишин О. В. Біохемія цукрового діабету: 1. Теоретична частина (огляд) / О. В. Кузишин, Н. В. Ковалишин, Н. В. Алмашина // Мед. хімія. 2010. - № 2. - C. 74-115.

2. Brownlee M. The pathobiology of diabetic complications: a unifying mechanism / M. Brownlee // Diabetes. - 2005. - 54 (6). - P. 1615-1625.

3. Дрель В. Р. Основні механізми виникнення та розвитку діабетичних ускладнень: роль нітративного стресу / В. Р. Дрель // Біологічні Студії. - 2010. - 4, № 2. - С. 141-158.
4. Pacher P. Nitric oxide and peroxynitrite in health and disease / P. Pacher, J. S. Beckman, L. Liaudet // Physiol. Rev. - 2007. - 87 (1). - P. 315-424.

5. Martyn J. A. Obesity-induced insulin resistance and hyperglycemia: etiologic factors and molecular mechanisms / J. A. Martyn, M. Kaneki, S. Yasuhara // Anesthesiology. - 2008. - 109 (1). - P. 137-148.

6. Бєленічев І. Ф. Антиоксидантна система захисту організму (огляд) / І. Ф. Бєленічев, Є. Л. Левицький, Ю. І. Губський // Совр. пробл. токсикол. - 2002. - № 3. C. 24-29. 
7. Дубинина Е. Е. Антиоксидантная система плазмы крови / Е. Е. Дубинина // Укр. биохим. журн. 1992. - 64, № 2. - С. 3-13.

8. Задоріна О. В. Ферменти антиоксидантної системи печінки щурів за умов отруєння хлоридом кадмію або 1,2-дихлоретаном / О. В. Задоріна // Совр. пробл. токсикол. - 2008. - № 3. - С. 68-72.

9. А. с. 1084681 СССР, МКИ G № 33/48. Способ определения гидроперекисей липидов в биологических тканях/В.В.Мирончик (СССР). -№ 3468369/2813; заявл. 08.07.82 ; опубл. 07.04.84, Бюл. № 13.

10. Коробейникова Э. Н. Модифрикация определения продуктов перекисного окисления липидов в реакции с тиобарбитуровой кислотой / Э. Н. Коробейникова // Лаб. дело. - 1989. - № 7. - С. 8-9.

11. Дубинина Е. Е. Активность и кофрерментный спектр СОД эритроцитов / Е. Е. Дубинина, Л. Я. Сальникова, Л. Ф. Ефримова // Лаб. дело. - 1983. - № 10. C. $30-33$.

12. Моин В. М. Простой и специфический метод определения активности глутатионпероксидазы в эритроцитах / В. М. Моин // Лаб. дело. - 1986. - № 12. C. 724-727.

13. Метод определения активности каталазы / М. А. Королюк, Л. И. Иванова, И. Г. Майорова, В. Е. Токарев // Лаб. дело. - 1988. - № 1. - С. 16-18.

14. Фізіолого-біохімічні методи досліджень у біології, тваринництві та ветеринарній медицині : довідник / [В. В. Влізло, Р. С. Федорук, І. А. Макар та ін.]. - Львів : ВМС, 2004. - 399 с.

15. Hissin P. J. A fluorometric method for determination of oxidized and reduced glutathione in tissues / P. J. Hissin, R. Hilf // Analytical Biochemistry. - 1976. 74. - P. 214-226.

16. Мокрий В. Я. Порушення системи перекисного окислення ліпідів при цукровому діабеті 2-го типу (огляд літератури) / В. Я. Мокрий, С. В. Зябліцев, Р. М. Борис // Міжнар. ендокрин. журн. - 2015. № 7 (71). - C. 41-44.

\section{REFERENCE}

1. Kuzyshyn, O.V., Kovalyshyn, N.V., \& Almashyna, H.V. (2010). Biokhimiia tsukrovoho diabetu: Teoretychna chastyna (ohliad) [Biochemistry of diabetes: Theoretical part (review)]. Medychna khimiia - Medical Chemistry, 2, 74-115 [in Ukrainian].

2. Brownlee, M. (2005). The pathobiology of diabetic complications: a unifying mechanism. Diabetes, 54 (6), 1615-1625.

3. Drel, V.R. (2010). Osnovni mekhanizmy vynyknennia ta rozvytku diabetychnykh uskladnen: rol nitratyvnoho stresu. [The basic mechanisms of diabetic complications and development: the role of nitrative stress]. Biolohichni Studii - Biological Studios, 4 (2), 41158 [in Ukrainian].

4. Pacher, P., Beckman, J.S., Liaudet, L.(2007). Nitric oxide and peroxynitrite in health and disease. Physiol., 87 (1), 315-424.
17. Занозина О. В. Роль окислительного стресса в развитии и прогрессировании поздних осложнений сахарного диабета 2-го типа. Возможности антиоксидантной терапии / О. В. Занозина // Междунар. эндокрин. журн. - 2010. - № 7 (31). - С. 127-136.

18. Sharma R. B. Lipotoxicity in the pancreatic beta cell: not just survival and function, but proliferation as well / R. B. Sharma, L. C. Alonso // Curr. Diab. Rep. 2014. - 4 (6). - P. 492.

19. Ma Z. A. The role of peroxidation of mitochondrial membrane phospholipids in pancreatic $\beta$-cell failure / Z. A. Ma // Curr. Diabetes Rev. -2012. -8 (1). - P. 69-75.

20. Протекторний вплив N-cтеароїлетаноламіну за гострої алкогольної інтоксикації у щурів / Н. М. Гула, Т. М. Горідько, Н. А. Стогній [та ін.] // Укр. біохім. журн. 2010. - 82, № 2. - C. 42-52.

21. Chen W. Y. Chromium attenuates hepatic damage in a rat model of chronic cholestasis / W. Y. Chen, C. J. Chen, J. W. Liao // Life Sciencesю - 2009. - 84. P. 606-614.

22. Турпаев К. Т. Активные формы кислорода и регуляция экспрессии генов / К. Т. Турпаев // Биохимия. - 2002. - 67, № 3. - С. 339-352.

23. Influence of organic zinc supplementation on the antioxidant status and immune responses of broilers challenged with Eimeria tenella // S. D. Bun, Y. M. Guo, F. C. Guo [et al.] // Poultry Science. - 2011. - 90 (6). P. 1220-1226.

24. Powell S. R. Antioxidant properties of zinc / S. R. Powell // J. Nutr. - 2000. - 130. - P. 1447-1454.

25. Kulikowska-Karpińska E. Lead and Zinc Influence on Antioxidant Enzyme Activity and Malondialdehyde Concentrations / Kulikowska-Karpińska E., Moniuszko-Jakoniuk J. // Polish Journal of Environmental Studies. - 2001. - 10 (3). P. 161-165.

26. Tate D. J. Zinc protects against oxidative damage in cultured human retinal pigment epithelial cells / D. J. Tate, M. V. Miceli, D. A. Newsome // Free Radic. Biol. Med. - 1999. - 26. - P. 704-713.

5. Martyn, J.A., Kaneki, M., Yasuhara, S. (2008). Obesity-induced insulin resistance and hyperglycemia: etiologic factors and molecular mechanisms. Anesthesiology, 109 (1), 137-148.

6. Bielenichev, I.F., Levytskyi, Ye.L., Hubskyi, Yu.I. (2002). Antyoksydantna systema zakhystu orhanizmu (ohliad) [The antioxidant defense system (review)]. Sovr. probl. toksykol - Modern Problems of Toxicology, 3, 2429 [in Ukrainian].

7. Dubinina, E.E.(1992). Antioksidantnaya sistema plazmy krovi. [Antioxidant system of blood plasma]. Ukr. byokhym. zhurn. - Ukrainian Biochemical Journal, 64 (2), 3-13 [in Ukrainian].

8. Zadorina, O.V. (2008). Fermenty antyoksydantnoi systemy pechinky shchuriv za umov otruiennia khlorydom kadmiiu abo 1.2-dykhloretanom [Antioxidant enzyme system of liver poisoning rats under cadmium chloride or 
1.2-dichloroethane]. Sovremennye problemy toksykologii - Modern Problems of Toxicology, 3, 68-72 [in Ukrainian].

9. A. s. № 1084681 SSSR, MKY` G № 33/48. Method for determining lipids hydroperoxides in biological tissues. Myronchyk V. V. (SSSR). - № 3468369/2813; zayavl. 08.07.82 ; opubl. 07.04.84, Byul. № 13 [in Russian].

10. Korobeynikova, Ye.N. (1989). Modyfikatsyya opredeleniya produktov perekysnogo okysleniya lipidov $\checkmark$ reaktsii s tiobarbyturovoy kislotoy. [Modification of definitions of products of peroxide oxidation of lipids in reaction with thiobarbituric acid]. Lab. Delo - Laboratory Case, 7, 8-9 [in Russian].

11. Dubynyna, E.E., Salnykova, L.Ya., \& Efimova, L.F. (1983). Aktyvnost i kofermentnyi spektr SOD erytrotsytov [The activity of SOD and coenzyme range of red blood cells]. Lab. Delo - Laboratory Case, 10, 30-33 [in Russian].

12. Moyn, B.M. (1986). Prostoy i spetsyficheskiy metod opredeleniya aktivnosti glutatyonperoksidazy v erytrotsytakh [Simple and specific method for determining the activity of glutathione peroxidase in erythrocytes]. Lab. Delo - Laboratory Case, 12, 724-727 [in Russian].

13. Korolyuk, M.A., Yvanova, L.Y., Mayorova, Y.G., \& Tokarev, V.E. (1988) Metod opredeleniya aktivnosti katalazy [The method for determining the activity of catalase]. Lab. delo - Laboratory Case, 1, 16-18 [in Russian].

14. Vlizlo, V.V., Fedoruk, R.S., \& Makar, I.A. (2004). Dovidnyk: Fizioloho-biokhimichni metody doslidzhen u biolohii, tvarynnytstvi ta veterynarnii medytsyni [Laboratory methods of research in biology, animal husbandry and veterinary medicine]. Lviv: «VMS» [in Ukrainian].

15. Hissin, P.J., \& Hilf, R. (1976). A fluorometric method for determination of oxidized and reduced glutathione in tissues. Analytical Biochemistry, 74, 214-226.

16. Mokryi, V.Ya., Zyablitsev, S.V., \& Borys, R.M. (2015). Porushennia systemy perekysnoho okyslennia lipidiv pry tsukrovomu diabeti 2-ho typu (ohliad literatury) [Violations of system lipid peroxidation in diabetes mellitus type 2 (literature review)]. Mizhnarodnyiendokrynolohichnyi zhurnal - International Endocrinological Journal, 7 (71) 1-44 [in Ukrainian].
17. Zanozyna, O.V. (2010). Rol okyslitelnogo stressa $\checkmark$ razvytii i progressirovanii pozdnikh oslozhneniy sakharnogo diabeta 2-go tipa. Vozmozhnosti antioksidantnoy terapii [The role of oxidative stress in development and prohressyrovanyy pozdnyh diabetes complications diabetes 2 nd type. Opportunity antioxidant therapy]. Mizhnarodnyi endokrynolohichnyi zhurnal - International Endocrinological Journal, 7 (31) [in Russian].

18. Sharma, R.B., \&Alonso, L.C. (2014). Lipotoxicity in the pancreatic beta cell: not just survival and function, but proliferation as well. Curr. Diab. Rep., 14 (6), 492. doi: 10.1007/ s11892-014-0492-2.

19. Ma Z.A. (2012). The role of peroxidation of mitochondrial membrane phospholipids in pancreatic $\beta$-cell failure. Curr. Diabetes Rev. 8(1), 69-75.

20. Hula, N.M., Horidko, T.M., Stohniy, N.A., Klimashevskyi V.M., \& Mehed O.F., (2010). Protektornyi vplyv $\mathrm{N}$-stearoiletanolaminu za hostroi alkoholnoi intoksykatsii u shchuriv [Protective effect of $\mathrm{N}$-stearoylethanolamine by acute alcohol intoxication in rats]. Ukrayinskyi biokhimichnyi zhurnal - Ukrainian Biochemical Journal, 82 (2), 42-52 [in Ukrainian].

21. Chen, W.Y., Chen, C.J., \& Liao, J.W. (2009). Chromium attenuates hepatic damage in a rat model of chronic cholestasis. Life Sciences, 84, 606-614.

22. Turpaev, K.T. (2002). Aktivnye formy kysloroda i regulyatsyya ekspresii [Active forms of oxygen and regulation of expression]. Biokhimiya - Biochemistry, 67 (3), 339-352 [in Russian].

23. Bun, S.D., Guo, Y.M., Guo, F.C., Ji F. J., \& Cao $H$. (2011). Influence of organic zinc supplementation on the antioxidant status and immune responses of broilers challenged with Eimeria tenella. Poultry Science, 90 (6), 1220-1226.

24. Powell S. R. 2000. Antioxidant properties of zinc. J. Nutr., 130, 1447-1454.

25. Kulikowska-Karpińska, E., \& Moniuszko-Jakoniuk, J. (2001). Lead and zinc influence on antioxidant enzyme activity and malondialdehyde concentrations. Polish Journal of Environmental Studies, 10 (3), 161-165.

26. Tate, D.J., Miceli, M.V., Newsome, D.A. (1999). Zinc protects against oxidative damage in cultured human retinal pigment epithelial cells. Free Radic. Biol. Med., $26,704-713$.

О. М. Слівінська, Р. Я. Іскра

ІНСТИТУТ БІОЛОГІЇ ТВАРИН НААН, ЛЬВІВ

\section{КОМПЛЕКСНИЙ ВПЛИВ ЦИТРАТІВ ХРОМУ І ЦИНКУ НА СИСТЕМУ АНТИОКСИДАНТНОГО ЗАХИСТУ В ОРГАНІЗМІ ЩУРІВ 3 ЕКСПЕРИМЕНТАЛЬНО ІНДУКОВАНИМ ЦУКРОВИМ ДІАБЕТОМ}

\section{Резюме}

Вступ. Оскільки цукровий діабет є генетично детермінованим захворюванням, особливе значення для людей з групи ризику мають профрілактичні заходи з метою відтермінувати початок захворювання 
або запобігти його виникненню. Тому важливо оцінити роль деяких мікроелементів у профрілактиці діабету. Зокрема, відомо, що цинк відіграє важливу роль при синтезі, накопиченні й вивільненні інсуліну $\beta$-клітинами підшлункової залози, а його синергіст хром зумовлює активацію інсулінових рецепторів на мембранах клітин.

Мета дослідження - з'ясувати дію цитратів хрому і цинку на фрункціонування антиоксидантної системи та вміст продуктів пероксидного окиснення ліпідів у крові й тканинах щурів при експериментальному цукровому діабеті, індукованому стрептозотоцином.

Методи дослідження. Дослідження проведено на білих лабораторних щурах, яких було поділено на три групи: 1-ша - контрольна; 2-га і 3-тя - дослідні. Щури 1-ї і 2-ї груп споживали виключно основний раціон, а тваринам 3-ї групи до питної води додавали розчини цитратів хрому та цинку в кількості, відповідно, 25 мке Cr/ке і 50 мг Zn/кг маси тіла. На 25-ту добу експерименту у тварин 2-ї і 3-ї дослідних груп на тлі 24-годинного голодування викликали експериментальний цукровий діабет шляхом внутрішньочеревного введення стрептозотоцину з розрахунку 45 мг/кг маси тіла. Матеріалом для досліджень були кров і тканини щурів, які відбирали після їх декапітації. У крові й тканинах визначали вміст гідропероксидів методом, принцип якого полягає в осадженні протеїну трихлороцтовою кислотою з наступним внесенням у середовище тіоціанату амонію. Концентрацію ТБК-активних продуктів визначали за допомогою кольорової реакції малонового діальдегіду з тіобарбітуровою кислотою, активність супероксиддисмутази - методом, принцип якого полягає у відновленні нітротетразолію супероксидними радикалами, активність глутатіонпероксидази - за швидкістю окиснення відновленого глутатіону, активність каталази - 3 урахуванням здатності пероксиду водню утворювати із солями молібдену стійкий кольоровий комплекс, активність глутатіонредуктази - за швидкістю відновлення глутатіону при наявності NADPH, вміст відновленого глутатіону - за рівнем утворення тіонітрофенільного аніона в результаті взаємодії SH-груп глутатіону з 5,5-дитіобіс-2-нітробензойною кислотою.

Результати й обговорення. У процесі виконання роботи встановлено, що за умов стрептозотоциніндукованого діабету в крові, печінці, скелетних м'язах та підилунковій залозі тварин 3-ї групи зростав рівень гідропероксидів ліпідів і ТБК-активних продуктів, однак зменшувались активність ензимів антиоксидантного захисту та вміст відновленого глутатіону. При комплексному додаванні до раціону щурів 3-ї групи цитратів хрому та цинку в досліджуваному матеріалі відзначали вірогідне зниження рівня продуктів пероксидного окиснення ліпідів та підвищення активності антиоксидантних ензимів відносно показників тварин 2-ї групи.

Висновки. Отримані результати свідчать про нормалізацію процесів пероксидного окиснення ліпідів та антиоксидантного захисту у тварин з гіперглікемією за умов впливу цитратів хрому і цинку. З'ясування антиоксидантних властивостей органічних сполук цих мікроелементів дозволить розробити на їх основі медичні засоби з метою профрілактики і лікування цукрового діабету.

КЛЮЧОВІ СЛОВА: щури; антиоксидантна система; цитрат цинку; цитрат хрому; експериментально індукований цукровий діабет.

\section{КОМПЛЕКСНОЕ ВОЗДЕЙСТВИЕ ЦИТРАТОВ ХРОМА И ЦИНКА НА СИСТЕМУ АНТИОКСИДАНТНОЙ ЗАЩИТЫ В ОРГАНИЗМЕ КРЫС С ЭКСПЕРИМЕНТАЛЬНО ИНДУЦИРОВАННЫМ САХАРНЫМ ДИАБЕТОМ}

\section{Резюме}

Вступление. Поскольку сахарный диабет является генетически детерминированным заболеванием, особое значение для людей из группы риска имеют профилактические мероприятия с целью отсрочить начало заболевания или предотвратить его возникновение. Поэтому важно оценить роль некоторых микроэлементов в профилактике диабета. В частности, известно, что цинк играет важную роль при синтезе, накоплении и высвобождении инсулина $\beta$-клетками поджелудочной железы, а его синергист хром обусловливает активацию инсулиновых рецепторов на мембранах клеток.

Цель исследования - выяснить действие цитратов хрома и цинка на функционирование антиоксидантной системы и содержание продуктов пероксидного окисления липидов в крови и тканях крыс при экспериментальном сахарном диабете, индуцированном стрептозотоцином.

Методы исследования. Исследования проведены на белых лабораторных крысах, которые были разделены на три группы: 1-я - контрольная; 2-я и 3-я - опытные. Крысы 1-й и 2-й групп употребляли 
исключительно основной рацион, а животным 3-й группы к питьевой воде добавляли растворы цитратов хрома и цинка в количестве, соответственно, 25 мкг Cr/кг и 50 мг Zn/ке массы тела. На 25-е сутки эксперимента у животных 2-й и 3-й опытных групп на фроне 24-часового голодания вызывали экспериментальный сахарный диабет путем внутрибрюшного введения стрептозотоцина из расчета 45 мг/кг массы тела. Материалом для исследований были кровь и ткани крыс, которые отбирали после их декапитации. В крови и тканях определяли содержание гидропероксидов методом, принцип которого заключается в осаждении протеина трихлоруксусной кислотой с последующим внесением в среду тиоцианата аммония. Концентрацию ТБК-активных продуктов определяли с помощью цветной реакции малонового диальдегида с тиобарбитуровой кислотой, активность супероксиддисмутазы - методом, принцип которого заключается в восстановлении нитротетразолия супероксидными радикалами, активность глутатионпероксидазы - по скорости окисления восстановленного глутатиона, активность каталазы с учетом способности пероксида водорода образовывать с солями молибдена стойкий цветной комплекс, активность глутатионредуктазы - по скорости восстановления глутатиона в присутствии NADPH, содержание восстановленного глутатиона - по уровню образования тионитрофренильного аниона в результате взаимодействия SH-групп глутатиона с 5,5-дитиобис-2-нитробензойной кислотой.

Результаты и обсуждение. В процессе выполнения работы установлено, что в условиях стептозотоцининдуцированного диабета в крови, печени, скелетных мышцах и поджелудочной железе животных 3-й группы возрастал уровень гидропероксидов липидов и ТБК-активных продуктов, однако уменьшались активность энзимов антиоксидантной защиты и содержание восстановленного глутатиона. При комплексном добавлении в рацион крыс 3-й группы цитратов хрома и цинка в исследуемом материале отмечали достоверное снижение уровня продуктов пероксидного окисления липидов и повышение активности антиоксидантных энзимов относительно показателей животных 2-й группы.

Выводы. Полученные результаты свидетельствуют о нормализации процессов пероксидного окисления липидов и антиоксидантной защиты у животных с гипергликемией при влиянии цитратов хрома и цинка. Выяснение антиоксидантных свойств органических соединений этих микроэлементов позволит разработать на их основе медицинские средства для профилактики и лечения сахарного диабета.

КЛЮЧЕВЫЕ СЛОВА: крысы; антиоксидантная система; цитрат цинка; цитрат хрома; экспериментально индуцированный диабет.

Received 24.01.17

Address for correspondence: O. M. Slivinska, Institute of animal biology NAAS, Vasyl Stus Street, 38, Lviv, 79034, Ukraine, e-mail: rudasliva@ukr.net. 